\title{
Administrasi Hubungan Sekolah dan Masyarakat (Husemas)
}

\author{
Yuni Kartika Sari \\ Universitas Negeri Padang \\ Indonesia \\ E-mail : (yunikartikasari446@gmail.com)
}

\begin{abstract}
Abstrak-This article is about how the relationship between the school and the community around the school, the purpose of which is to improve the community about the importance of education for the surrounding community so that there is a good cooperative relationship in the community, the method used in this article is descriptive methods and techniques. Can be used in the form of writing techniques, oral techniques, and electronics so that between the school and the community can establish good communication. The success of educational institutions must be carried out by all parties, whether they are schools, families or communities. In this case, these three components must work together in realizing quality education. For this reason, schools are expected to be able to improve relations with families, as well as the community, which in general are invited to work together in realizing the management of school and community relations well, in order to achieve educational goals. This scientific article is structured with systematic methods and steps to facilitate conducting research. The researcher used the literature study method by collecting literature, materials sourced from books, journals, and other sources related to the science of the Administration of School and Community Relations.
\end{abstract}

Keywords-(Administrasi Hubungan Sekolah Dengan

\section{PENDAHULUAN}

Dilihat dari konsep pendidikan, masyarakat adalah sekumpulan orang dengan berbagai ragam kualitas diri yang tidak berpendidikan sampai dengan yang berpendidikan. Sementara itu, dilihat dari lingkungan pendidikan, masyarakat disebut lingkungan nonformal yang memberikan pendidikan secara sengaja dan berencana kepada seluruh anggotanya, tetapi tidak sistematis.

Mohammad Noor Syam, dalam bukunya Filsafat Pendidikan dan Dasar Filsafat Pendidikan Pancasila, mengemukakan bahwa hubungan masyarakat dengan pendidikan sangat bersifat korelatif, bahkan seperti telur dengan ayam. Masyarakat maju karena pendidikan dan pendidikan yang maju hanya akan ditemukan dalam masyarakat yang maju. Sekolah juga berfungsi sebagai lembaga sosial yang melayani anggota-anggota masyarakat dalam bidang pendidikan.

Berbagai persoalan yang dihadapi oleh dunia pendidikan sampai lembaga pendidikan di era globalisasi dan desentralistik (otonomi daerah) menuntut team work yang solid antara pihak sekolah itu sendiri dengan pihak luar, baik instansi atasan maupun masyarakat. Melalui Manajemen
Berbasis Sekolah, maka administrasi hubungan sekolah dengan masyarakat menjadi kunci sukses di dalamnya. Dan ketika hubungan sekolah dengan masyarakat ini dapat berjalan harmonis dan dinamis dengan sifat pedagogis, sosiologis dan produktif, maka diharapkan tercapai tujuan utama yaitu terlaksananya proses pendidikan di sekolah secara produktif, efektif, efisien dan berhasil sehingga menghasilkan out-put yang berkualitas secara inteletual, spritual dan sosial.

Sekolah berada ditengah-tengah masyarakat dan dapat dikatakan sebagai pisau bermata dua. Mata yang pertama adalah menjaga kelestarian nilai-nilai positif yang ada dalam masyarakat, agar pewarisan nilai-nilai masyarakat berlangsung dengan baik. Mata uang kedua adalah sebagai lembaga yang dapat mendorong perubahan nilai dan tradisi sesuai dengan kemajuan dan tuntutan kehidupan serta pembangunan. Kedua fungsi ini seolah-olah bertentangan, namun sebenarnya keduanya dilakukan dalam waktu yang bersamaan.

Oleh karena itu fungsi yang controversial ini, diperlukan saling pemahaman antara sekolah dan masyrakat.

Nilai-nilai yang sesuai dengan kebutuhan pembangunan tetap dijaga kelestariannya, sedang yang tidak sesuai harus diubah. Pelaksanaan fungsi sekolah ini, terlebih sekolah menengah yang berada di tengah-tengah masyrakat terpencil, menjadi tumpuan harapan masyrakat untuk kemajuan mereka. Untuk dapat menjalankan fungsi ini hubungan sekolah masyarakat harus selalu baik. Dengan demikian, terdapat kerjasama serta situasi saling membantu antara sekolah dan masyrakat. Disamping itu, pendidikan merupakan tanggung jawab bersama antara sekolah, pemerintah, dan masyarakat. Realisasi tanggung jawab itu tidak dapat dilaksanakan apabila hubungan sekolah dan masyrakat tidak terjalin sebaik-baiknya.

Hubungan sekolah dan masyarakat atau dikenal dengan istilah Husemas termasuk salah satu dalam administrasi pendidikan. Sekolah merupakan konsep yang luas, yang mencakup lembaga pendidikan formal maupun lembaga pendidikan non formal sedangkan masyarakat merupakan konsep yang mengacu kepada semua individu, kelompok, lembaga atau organisasi yang berada diluar sekolah sebagai lembaga pendidikan.

Berdasarkan penjelasan diatas, maka artikel ini bertujuan untuk menjelaskan kepada para pembaca mengenai hubungan sekolah dan masyarakat dan bagaimana peran guru dalam hubungan sekolah dan masyarakat. 


\section{Metode Penelitian}

Artikel ilmiah seharusnya disusun dengan metode dan langkah-langkah yang sistematis. Pada artikel ini, penulis menggunakan metode mengumpulkan bahan dan materi dari buku, jurnal, artikel, dan sumber lain yang berkaitan dengan administrasi hubungan sekolah dan masyarakat. Metode literatur yang berhubungan dengan topik yang diminati dapat membantu mempermudah dalam merumuskan masalah penelitian, metode ini disebut juga dengan metode SLR (Systematic Literature Review). Setelah bahan kajian dan materi dikumpulkan, kemudian diteliti. Penulis nantinya menyimpulkan pengetahuan yang penulis dapatkan dari materi tersebut. Metode literatur ini bertujuan untuk membantu menemukan wawasan, kebenaran dan juga penyelesaian dari masalah yang dihadapi. Sebagai petunjuk yang terbukti kebenarannya sebaiknya menggunakan buku-buku dengan tanngal hak cipta baru. Semakin baru sebuah buku ditulis maka semakin cocok dengan zaman dari materi yang akan ditelaah/dipelajari.

\section{KAJIAN TEORI DAN PEMBAHASAN}

\section{A. Pengertian Administrasi Pendidikan}

Kata "administrasi" berasal dari bahasa Latin yang teridiri dari kata ad yang berarti "ke" atau "kepada" dan ministrate yang berarti "melayani", "membantu", atau "mengrahkan". Dapat disimpulkan bahwa kata administrasi adalah suatu kegiatan untuk membantu, melayani, mengarahkan, atau mengatur semua kegiatan dalam mencapai tujuan tertentu. Hubungan sekolah dengan masyarakat pada hakikatnya merupakan suatu sarana yang sangat berperan dalam membina dan mengembangkan pertumbuhan pribadi peserta didik di sekolah. sekolah sebagai sistem sosial merupakan bagian integral dari sistem sosial yang lebih besar yaitu masyarakat.

Sekolah dan masyarakat memiliki hubungan yang sangat erat dalam mencapai tujuan sekolah atau pendidikan secara efektif dan efisien. Sebaliknya sekolah juga harus menunjang pencapaian tujuan atau pemenuhan masyarakat, khususnya kebutuhan pendidikan. Sehingga jelaslah antara sekolah dan masyarakat harus dibina suatu hubungan yang harmonis (Mulyasa, 2004).

Administrasi Hubungan Sekolah dengan Masyarakat merupakan suatu proses komunikasi antara sekolah dan masyarakat untuk meningkatkan pengertian masyarakat tentang kebutuhan serta kegiatan pendidikan serta mendorong minat dan kerjasama masyarakat dalam peningkatan dan pengembangan sekolah. (Afriansyah, 2019b).

Defini diatas mengandung 3 element penting yaitu, adanya: 1) Kepentingan yang sama antara sekolah dan masyarakat. 2) Peran penting dalam pengembangan sekolah, untuk memenuhi harapan masyarakat. 3) Komunikasi dua arah yang efisien, untuk meningkatkan kerja sama yang baik (Afriansyah, 2019a).

\section{B. Prinsip dan Teknik Administrasi Hubungan Sekolah dan Masyarakat}

\section{Prinsip Administrasi Husemas}

\section{a) Integrity}

Prinsip ini mengandung makna bahwa semua kegiatan hubungan sekolah dengan masyarakat harus terpadu, dalam arti apa yang dijelaskan, disampaikan dan disuguhkan kepada masyarakat harus informasi yang terpadu antara informasi kegiatan akademik maupun informasi kegiatan yang bersifat non akademik. Biasanya sering terjadi sekolah tidak menginformasikan atau menutupi sesuatu yang sebenarnya menjadi masalah sekolah dan perlu bantuan atau dukungan orang tua murid. Oleh sebab itu, sekolah harus sedini mungkin mengantisipasi kemungkinan adanya salah persepsi, salah interprestasi tentang informasi yang disajikan dengan melengkapi informasi yang akurat dan data yang lengkap, sehingga dapat diterima secara rasional oleh masyarakat. Hal ini sangat penting untuk meningkatkan penilaian dan kepercayaan masyarakat atau orang tua murid terhadapsekolah, atau dengan kata lain transparansi sekolah sangat diperlukan, lebih dalam era reformasi dan abad informasi ini, masyarakat akan semakin kritis dan berani memberikan penilaian secara langsung tentang sekolah.

b) Continuity

Prinsip ini berarti bahwa pelaksanaan hubungan sekolah dengan masyarakat, harus dilakukan secara terus menerus. Jadi, pelaksanaan hubungan sekolah dengan masyarakat tidak hanya dilakukan secara insedental atau sewaktu-waktu, misalanya satu kali dalam satu tahun atau sekali dalam satu semester, hanya dilakukan oleh sekolah ada saat akan meminta bantuan keuangan kepada orang tua atau masyarakat. Hal inilah yang menyebabkan masyarakat selalu beranggapan apabila ada panggilan sekolah untuk datang ke sekolah selalu dikaitkan dengan uang. Akibatnya mereka cenderung untuk tidak menghadiri atau sekedar mewakilkan kepada orang lain untuk menghadiri undangan sekolah. Apabila ini terkondisi, maka sekolah akan sulit mendapat dukungan yang kuat dari semua orang tua murid dam masyarakat. Perkembangan informasi, perkembangan kemajuan sekolah, permasalahan-permasalahan sekolah bahkan, permasalahan belajar siswa selalu muncul dan berkembang setiap saat, karena itu maka diperlukan penjelasan informasi yang terus menerus dari sekolah untuk masyarakat atau orang tua murid, sehingga mereka sadar akan pentingnya keikutsertaan ,mereka dalam meningkatkan mutu pendidikan putra-putrinya.

c) Simplicity

Prinsip ini menghendaki agar dalam proses hubungan sekolah dengan masyarakat yang dilakukan baik komunikasi personal maupun komunikasi kelompok pihak pemberi informasi (sekolah) dapat menyederhanakan berbagai informasi yang disajikan kepada masyarakat. Informasi yang disajikan kepada masyarakat melalui pertemuan langsung maupun melalui media hendaknya disajikan dalam bentuk sederhana sesuai dengan kondisi dan karakteristik pendengar (masyarakat setempat). 
Administrasi Hubungan Sekolah dan Masyarakat, Padang 2019 Prinsip kesederhanaan ini juga mengandung makna bahwa informasi yang disajikan dinyatakan dengan kata-kata yang penuh persahabatan dan mudah dimengerti. Banyak masyarakat yang tidak memahami istilah-istilah yang sangat ilmiah, oleh sebab itu, penggunaan istilah sedapat mungkin disesuaikan dengan tingkat pemahaman masyarakat. d) Coverage

Kegiatan pemberian informasi hendaknya menyeluruh dan mencakup semua aspek, faktor atau substansi yang perlu disampaikan dan diketahui oleh masyarakat, misalnya program ekstra kurikuler, kegiatan kurikuler, remedial teaching dan lain-lain kegiatan. Prinsip ini juga mengandung makna bahwa segala informasi hendaknya: a. Lengkap Artinya tidak satu informasipun yang harus ditutupi atau disimpan, padahal masyarakat atau orang tua murid mempunyai hak untuk mengetahui keberadaan dan kemajuan sekolah dimana anaknya belajar. Oleh sebab itu, informasi kemajuan sekolah, masalah yang dihadapi sekolah serta prestasi yang dapat dicapai sekolah harus diinformasikan kepada masyarakat. b. Akurat Artinya informasi yang diberikan memang tepat dan sesuai dengan kebutuhan masyarakat, dalam kaitannya ini juga berarti bahwa informasi yang diberikan jangan dibuat-buat atau informasi yang obyektif. c. Up to date Berarti informasi yang diberikan adalah informasi perkembangan, kemajuan, masalah dan prestasi sekolah terakhir.

e) Constructiveness

Program hubungan sekolah dengan masyarakat hendaknya konstruktif dalam arti sekolah memberikan informasi yang konstruktif kepada masyarakat. Dengan demikian masyarakat akan memberikan respon hal-hal positif tentang sekolah serta mengerti dan memahami secara detail berbagai masalah yang dihadapi sekolah. Apabila hal tersebut dapat mereka mengerti, akan merupakan salah satu faktor yang dapat mendorong mereka untuk memberikan bantuan kepada sekolah sesuai dengan permasalahan sekolah yang perlu mendapat perhatian dan pemecahan bersama. Hal ini, menuntut sekolah untuk membuat daftar masalah yang perlu dikomunikasikan secara terus menerus kepada sasaran masyarakat tertentu.

f) Adaptability

Program hubungan sekolah dengan masyarakat hendaknya disesuaikan dengan keadaan di dalam lingkungan masyarakat tersebut. Penyesuaian dalam hal ini termasuk penyesuaian terhadap aktivitas, kebiasaan, budaya (culture) dan bahan informasi yang ada dan berlaku di dalam kehidupan masyarakat. Bahkan pelaksanaan kegiatan hubungan dengan masyarakat pun harus disesuaikan dengan kondisi masyarakat. Misalnya saja masyarakat daerah pertanian yang setiap pagi bekerja di sawah, tidak mungkin sekolah mengadakan kunjungan (home visit) pada pagi hari.

\section{Teknik Administrasi Husemas}

Kenyataan membuktikan, hubungan sekolah dengan masyarakat tidak selalu berjalan baik. Berbagai kendala yang sering ditemukan antara lain adalah komunikasi, yang terhambat dan tidak professional, tindak lanjut program yang tidak lancar dan pengawasan yang tidak terstruktur. Untuk mengatasi berbagai kendala tersebut beberapa hal bisa menjadi altenatif, adanya laporan berkala mengenai berbagai kegiatan sekolah serta keuangannya, diadakannya berbagai kegiatan yang mengakrabkan seperti open house kunjungan timbal balik dan program kegiatan bersama seperti pentas seni dan perpisahan. Ada sejumlah teknik yang kiranya dapat diterapkan oleh lembaga pendidikan, teknik-teknik tersebut dapat dikelompokkan menjadi empat, yaitu teknik tertulis, teknik lisan, teknik peragaan dan teknik elektronik.

a) Teknik Tertulis

Hubungan antara sekolah dan masyarakat dapat dilakukan secara tertulis, cara tertulis yang dapat digunakan adalah :

- Buku kecil pada permulaan tahun ajaran Buku kecil pada permulaan tahun ajaran baru ini isinya menjelaskan tentang tata tertib, syarat-syarat masuk, hari-hari libur, hari-hari efektif. Kemudian buku kecil ini dibagikan kepada orang tua murid, hal ini biasanya dilaksanakan di taman kanak-kanak (TK).

- Pamflet Merupakan selembaran yang biasanya berisi tentang sejarah lembaga pendidikan tersebut, staf pengajar, fasilitas yang tersedia, dan kegiatan belajar. Pamflet ini selain di bagikan ke wali murid jga bisa di sebarkan ke masyarakat umum, selain untuk menumbuhkan pengertian masyarakat juga sekaligus untuk promosi lembaga.

- Berita kegiatan murid Berita ini dapat dibuat sederhana mungkin pada selebaran kertas yang berisi informasi singkat tentang kegiatan-kegiatan yang dilakukan di sekolah ataupun pesantren. Dengan membacanya orang tua murid mengetahui apa yang terjadi di lembaga pendidikan tersebut, khususnya kegiatan yang dilakukan murid.

- Catatan berita gembira Teknik ini sebenarnya mirip dengan berita kegiatan murid, keduanya sama-sama ditulis dan disebarkan ke orang tua. Hanya saja catatan berita gembira ini berisi tentang keberhasilan seorang murid. Berita tersebut ditulis di selebaran kertas dan disampaikan kepada wali murid atau bahkan disebarkan ke masyarakat.

- Buku kecil tentang cara membimbing anak Dalam rangka menciptakan hubungan yang harmonis dengan orang tua, kepala sekolah atau guru dapat membuat sebuah buku kecil yang sederhana yang berisi tentang cara membimbing anak yang efektif, kemudian buku tersebut diberikan kepada orang tua murid.

\section{b) Teknik Lisan}

Hubungan sekolah dengan masyarakat dapat juga secara lisan, yaitu:

$\sigma$ Kunjungan rumah Dalam rangka mengadakan hubungan dengan masyarakat, pihak sekolah dapat mengadakan kunjungan ke rumah wali murid, warga ataupun tokoh masyarakat. Melalui kunjungan rumah ini guru akan mengetahui masalah anak dirumahnya. Apabila setiap anak diketahui problemnya secara totalitas, maka program pendidikan akan lebih mudah direncanakan untuk disesuaikan dengan minatnya. 
$\sigma$ Mengundang orang tua Selain mengadakan kunjungan ke rumah, pihak sekolah sesekali juga mengundang orang tua murid datang ke sekolah. Setelah datang, mereka diberi penjelasan tentang perkembangan pendidikan di lembaga tersebut. Mereka juga perlu diberi penjelasan khusus tentang perkembangan pendidikan anaknya.

$\sigma$ Pertemuan Dengan teknik ini berarti sekolah mengundang masyarakat dalam acara pertemuan khusus untuk membicarakan masalah atau hambatan yang dihadapi sekolah. Pertemuan ini sebaiknya diadakan pada waktu tertentu yang dapat dihadiri oleh semua pihak yang diundang. Sebelum pertemuan dimulai acaranya disusun terlebih dahulu. Oleh karena itu, setiap akan mengadakan pertemuan sebaiknya dibentuk panitia penyelenggara.

c) Teknik Peragaan Hubungan sekolah dengan masyarakat dapat dilakukan dengan cara mengundang masyarakat melihat peragaan yang diselenggarakan sekolah. Peragaan yang diselenggarakan biasanya berupa pameran keberhasilan murid. Misalkan di TK menampilkan anak-anak bernyanyi, membaca puisi dan menari. Pada kesempatan itu kepala sekolah atau guru TK tersebut dapat menyampaikan program-program peningkatan mutu pendidikan dan juga masalah atau hambatan yang dihadapi dalam merealisasikan program-program itu.

\section{d) Teknik Elektronik}

seiring dengan perkembangan teknologi elektronik maka dalam mengakrabkan sekolah dengan orang tua murid dan masyarakat pihak sekolah dapat menggunakan sarana elektronik, misalkan dengan telepon, televise, ataupun radio, sekaligus sebagai sarana untuk promosi pendidikan.

\section{Proses Administrasi Husemas}

\section{Penyusunan Program}

Penyusunan program husemas memperhatikan dana yang tersedia, ciri masyarakat, daerah jangkauan, sarana atau media, dan teknik yang akan dilaksanakan dalam mengadakan hubungan dengan masyarakat. Jika perencanaan tidak memperhatikan hal-hal tersebut, di khawatirkan kegiatan tersebut tidak akan mencapai sasaran yang di inginkan.

\section{Pelaksanaan atau Pengorganisasian}

Pada dasarnya semua komponen sekolah dan pelaksanaan husemas. Oleh karena itu, tugas-tugas mereka perlu dipahami dan ditata, sehingga penyelenggara husemas dapat berjalan efektif dan efisien. Dalam pelaksanaan husemas perlu diperhatikan koordinasi antara berbagai bagian dan kegiatan, dan di dalam penggunaan waktu perlu adanya sinkronisasi.

3. Pengawasan Pengawasan pada administrasi hubungan sekolah dan masyarakat dapat berupa evaluasi.

Husemas dapat di evaluasi melalui dua kriteria,

yaitu:

a) Efektifitas, yaitu sejauh apa tujuan tercapai

b) Efisiensi, yaitu mengenai sumber dan potensi dengan baik.

\section{Peran Personil Sekolah dalam Administrasi Husemas}

Guru merupakan kunci penting dalam kegiatan husemas di sekolah menengah. Ada beberapa hal yang dapat dilakukan guru dalam kegiatan husemas itu, yaitu :

1. Membantu sekolah dalam melaksanakan teknikteknik husemas.

Meskipun kepala sekolah orang kunci dalam pengelolaan husemas, akan tetapi kepala sekolah tidak mungkin melaksanakan program husemas tanpa bantuan guruguru. Guru-guru dapat ditugasi kepala sekolah melaksanakan hal-hal yang berkaitan dengan husemas, disesuaikan dengan jenis dan bentuk kegiatan yang ada.

2. Membuat dirinya lebih baik lagi dalam bermasyarakat.

Guru adalah tokoh milik bagi masyarakat, tingkah laku yang dilakukan guru disekolah dan di masyarakat menjadi sesuatu yang sangat penting karena guru menjadi panutan di masyarakat.

3. Dalam melaksanakan semua itu guru harus melaksanakan kode etiknya.

Kode etik guru merupakan aturan atau rambu-rambu yang perlu diikuti dan tidak boleh dilanggar oleh guru. Kode etik mengatur guru menjadi manusia terpuji di masyarakat karena kode etik merupakan cerminan kehendak masyarakat terhadap guru, maka menjadi kewajiban guru untuk melaksanakan dan mengikutinya (kode etik guru) (Afriansyah, 2019).

\section{KESIMPULAN}

Administrasi pendidikan merupakan sistem kerja sama di antara personel pendidikan untuk mencapai tujuan pendidikan untuk mencapai tujuan pendidikan. Kerjasama ini dilakukan dengan memanfaatkan sumber daya, baik sumber manusia maupun non-manusia. Administrasi pendidikan mempunyai lingkup garapan yang luas, antara lain kurikulum, kesiswaan personel, keuangan, hubungan sekolah drengan masyarakat, serta layanan khusus. Humas sebagai penghubung dari pihak sekolah dengan masyarakat harus selalu dipelihara dengan baik karena sekolah akan selalu berhubungan dengan masyarakat, tidak bisa lepas darinya sebagai partner sekolah dalam mencapai kesuksesan sekolah itu sendiri. Prestise sekolah semakin tinggi di mata masyarakat jika sekolah mampu melahirkan peserta didik yang cerdas, berkepribadian dan mampu mengaplikasikan ilmu yang diperolehnya dalam memajukan masyarakat.

\section{Daftar Pustaka}

Afriansyah, H. (2019). Administrasi Peserta Didik. Padang. https://doi.org/10.17605/OSF.IO/NRXH8

Afriansyah, H. (2019a). Administrasi Hubungan Sekolah dan Masyarakat. https://doi.org/10.17605/OSF.IO/X4U2D

Mulyasa. (2004). Manajemen Berbasis Sekolah. Bandung: Remaja Rosdakarya 
